\title{
FAKTOR YANG MEMPENGARUHI MATURITAS MANAJEMEN RISIKO ORGANISASI DI INDONESIA
}

\author{
Dr. Antonius Alijoyo ${ }^{1}$, \\ Center for Risk Management and Sustainability \\ Yusuf Munawar ${ }^{2}$, \\ Universitas Katolik Parahyangan
}

\begin{abstract}
Risk management maturity (RMM) is often used as an indicator to show the effectiveness of the organization's risk management implementation. This paper discusses the factors that affect the achievement of the level of maturity in the application of risk management in organizations. Data obtained through a survey involving 55 respondents who are practitioners of risk management and processed using contingency table analysis techniques. Based on the results of data processing, the aspects that support the maturity level of the organization's risk management are related to a clear governance structure, guidelines and procedures, leadership's commitment and periodic reviews, human resources who have competence in the field of risk management to create culture of risk awareness, integrated management and performance management system, as well as organizational resilience and sustainability management systems.
\end{abstract}

Key words: Risk Management; Maturity; Contingency Table; Leadership;Resilience, Sustainability.

\begin{abstract}
ABSTRAK
Maturitas manajemen risiko sering digunakan sebagai indikator untuk menunjukan efektivitas penerapan manajemen risiko organisasi. Paper ini membahas mengenai faktor-faktor yang mempengaruhi pencapaian tingkat maturitas dalam penerapan manajemen risiko di organisasi. Data diperoleh dari survei yang melibatkan 55 responden yang merupakan para praktisi bidang manajemen risiko dan diolah dengan menggunakan teknik contigency table analysis. Berdasarkan hasil pengolahan data, aspek yang menunjang terhadap tingkat maturitas manajemen risiko organisasi terkait dengan struktur governance, pedoman, dan prosedur yang jelas serta didukung oleh komitmen pimpinan dan kaji ulang secara berkala, sumber daya manusia yang memiliki kompetensi dalam bidang manajemen risiko untuk menciptakan budaya sadar risiko organisasi, pengelolaan sistem manajemen dan kinerja yang terintegrasi, serta sistem pengelolaan ketahanan dan keberlanjutan organisasi.
\end{abstract}

Kata kunci:Manajemen Risiko, Maturitas, Kepemimpinan, Ketahanan, Keberlanjutan.

Klasifikasi JEL:G32; M500; Q56

\footnotetext{
${ }^{1}$ Principal Center for Risk Management and Sustainability (CRMS) Indonesia

2 Dosen Program Studi Ekonomi Pembangunan.email: yusuf.munawar@unpar.ac.id
} 


\section{PENDAHULUAN}

Kebutuhan penerapan manajemen risiko semakin nyata bagi organisasi di berbagai sektor karena mampu mempengaruhi kemampuan organisasi untuk menciptakan dan melindungi nilai (Karyani et al, 2016; Yang et al, 2018). Selain itu, dalam konteks Indonesia, manajemen risiko sudah menjadi agenda nasional yang tercantum dalam Rencana Pembangunan Jangka Menengah Nasional (RPJMN) Pemerintah Indonesia tahun 2020-2024 dimana ditetapkan bahwa manajemen risiko menjadi pilar dalam pengelolaan kinerja instansi pemerintah.

Penerapan manajemen risiko di organisasi harus terus dikembangkan dan dievaluasi efektivitas penerapannya. Untuk melakukan evaluasi dan menilai tingkat efektivitas dari penerapan manajemen risiko organisasi, organisasi bisa menggunakan mekanisme pengukuran maturitas terhadap penerapan manajemen risiko. Capaian maturitas yang tinggi sering digambarkan sebagai suatu kondisi yang menunjukan bahwa manajemen risiko telah berjalan secara efektif di organisasi.

Untuk meningkatkan efektivitas dan capaian tingkat maturitas yang lebih tinggi, organisasi perlu mengetahui faktor apa saja yang dapat mempengaruhi tingkat maturitas yang tinggi dalam penerapan manajemen risiko bagi organisasi.Secara umum, faktor yang mempengaruhi dapat dikelompokan menjadi dua, yaitu faktor yang berasal dari internal serta faktor yang berasal dari eksternal. Faktor yang berasal dari eksternal diantaranya adalah ketersediaan regulasi yang akan mendorong organisasi untuk mematuhi regulasi dan jika organisasi bisa mengelola kepatuhan tersebut maka implementasi manajemen risiko akan efektif (Shimpi, 2005). Sementara itu, faktor internal yang dapat mempengaruhi efektivitas manajemen risiko antara lain: komitmen pimpinan puncak (Ranong \& Phuenngam, 2009; Kikwasi, 2018; Zhao et al, 2013; Mensah \& Gottwald, 2015; Kabuye et al, 2019), dukungan sumber daya manusia yang kompeten (Priyarsono \& Munawar, 2020), kualitas audit (Drogalas et al, 2017), serta faktor budaya (Sari et al, 2018; Agarwal \& Kallapur, 2018; Kurniawan et al, 2017).

Alijoyo et al (2020) menyatakan bahwa tingkat capaian maturitas manajemen risiko yang juga akan menggambarkan tingkat efektivitas penerapan manajemen risiko akan sangat dipengaruhi oleh karakteristik organisasi. Sebagian besar penelitian terdahulu, sebagaimana disebutkan sebelumnya, menelaah faktor yang mempengaruhi efektivitas manajemen risiko bukan dalam konteks Indonesia. Hanya penelitian Priyarsono \& Munawar (2020) serta Sari et al (2018) yang meneliti dalam konteks Indonesia. Priyarsono \& Munawar (2020) meneliti hubungan antara faktor sumber daya manusia (SDM) terhadap peningkatan efektivitas manajemen risiko organisasi. Sementara itu, Sari et al (2018) meneliti mengenai budaya organisasi yang akan mendorong pencapaian kinerja organisasi. Kedua penelitian tersebut tidak secara lengkap menjawab pertanyaan mengenai faktor apa saja yang dapat mempengaruhi efektivitas dan pencapaian maturitas manajemen risiko organisasi. Untuk itu, paper ini mencoba melengkapi sudut pandang yang lebih lengkap mengenai faktor lainnya selain SDM dan budaya organisasi yang akan mempengaruhi pencapaian tingkat maturitas dalam penerapan manajemen risiko di organisasi, khususnya dalam konteks Indonesia. Dengan mengetahui faktor apa yang mempengaruhi capaian maturitas dalam penerapan manajemen risiko, organisasi bisa merumuskan kebijakan atau program kerja yang tepat.

\section{METODE PENELITIAN}

Untuk mencapai tujuan penelitian, peneliti menggunakan pendekatan kualitatif dan kuantitatif. Pendekatan kualitatif digunakan untuk memperoleh persepsi, pemahaman, serta 
kondisi responden dalam konteks maturitas manajemen risiko. Data mengenai persepsi, pemahaman, serta kondisi responden tersebut diperoleh melalui kuesioner yang disediakan secara daring (online) di situs internet dan tanggapan responden atas pertanyaan dalam kuesioner merupakan categorical data. Kuesioner yang terkumpul dan terisi secara valid untuk digunakan dalam penelitian ini berjumlah 55 (lima puluh lima).

Setelah data kualitatif diperoleh, pendekatan kuantitatif digunakan untuk memaknai data yang diperoleh dan menjawab pertanyaan penelitian mengenai faktor yang mempengaruhi maturitas manajemen risiko organisasi dengan menggunakan deskripsi tabel satu arah dan tabel dua arah (cross table). Pada tabel satu arah, data dianalisis berdasarkan distribusi persentasenya. Sementara pada tabel dua arah (cross table) data diolah dengan dengan menggunakan metode contingency table analysis. Contingency table analysis digunakan dalam penelitian karena jawaban responden merupakan categorical data dan contingency table analysis merupakan metode yang bisa digunakan untuk menguji keterkaitan antar 2 variabel dengan klasifikasi categorical data (misalnya X dan Y) (Kateri, 2014). Hipotesis dalam pengujian contigency table analysis dapat dituliskan sebagai berikut:

$H_{0}$ : Tidak terdapat hubungan antara variabel $\mathrm{X}$ dan $\mathrm{Y}$.

$H_{1}$ : Terdapat hubungan antara variabel X dan Y.

Mekanisme pengaplikasian metode contingency table analysis dijabarkan dalam tabel 1 yang akan digunakan untuk menguji asosiasi antara dua variable, dengan empat kategori pengelompokan (Priyarsono \& Munawar, 2020).

Tabel 1. Ilustrasi penerapan teknik contingency table analysis

\begin{tabular}{|c|c|c|c|c|c|}
\hline \multirow{2}{*}{$\mathbf{X}$} & \multicolumn{4}{|c|}{$\mathbf{Y}$} & \multirow{2}{*}{ Jumlah } \\
\hline & 1 & 2 & 3 & 4 & \\
\hline \multirow{2}{*}{1} & $a_{11}$ & $a_{12}$ & $a_{13}$ & $a_{14}$ & $a_{1}$ \\
\hline & $\mathrm{e}_{11}$ & $e_{12}$ & $\mathrm{e}_{13}$ & $e_{14}$ & \\
\hline \multirow{2}{*}{2} & $a_{21}$ & $a_{22}$ & $a_{23}$ & $a_{24}$ & $a_{2}$ \\
\hline & $\mathrm{e}_{21}$ & $\mathrm{e}_{22}$ & $\mathrm{e}_{23}$ & $e_{24}$ & \\
\hline \multirow{2}{*}{3} & $a_{31}$ & $a_{32}$ & $a_{33}$ & $a_{34}$ & $a_{3 .}$ \\
\hline & $\mathrm{e}_{31}$ & $e_{32}$ & $\mathrm{e}_{33}$ & $e_{34}$ & \\
\hline \multirow{2}{*}{4} & $\mathrm{a}_{41}$ & $a_{42}$ & $a_{43}$ & $\mathrm{a}_{44}$ & $\mathrm{a}_{4}$. \\
\hline & $\mathrm{e}_{41}$ & $e_{42}$ & $\mathrm{e}_{43}$ & $e_{44}$ & \\
\hline Jumlah & $\mathrm{a}_{.1}$ & $\mathrm{a}_{.2}$ & $\mathrm{a}_{3} 3$ & $\mathrm{a}_{.4}$ & $\mathrm{a}_{. .}$ \\
\hline
\end{tabular}

Sebagai ilustrasi, dalam Tabel 1, terdapat nilai amatan (observed value) $\mathrm{a}_{12}$ yang menunjukan kombinasi variabel X pada kelompok 1 dan variabel Y pada kelompok 2 . Dengan kata lain, angka pertama pada subskrip menyatakan kelompok untuk variabel X, sedangkan angka kedua menyatakan kelompok pada variabel Y. Nilai amatan diperoleh dari data yang dijaring melalui survei. Adapun expected value (nilai ekspektasi), diperoleh dengan rumus berikut:

$$
\mathrm{e}_{\mathrm{ij}}=\frac{\left(a_{i}\right)-\left(a_{j}\right)}{\left(a_{\ldots}\right)}, \text { untuk } \mathrm{i}=1, \ldots, \mathrm{n}, \text { dan } \mathrm{j}=1, \ldots \mathrm{n} \text {. }
$$

Kemudian, nilai chi-square ditentukan dengan rumus: 


$$
X^{2}=\sum \sum \frac{\left(a_{i j}-e_{i j}\right)^{2}}{e_{i j}}, \text { untuk } \mathrm{i}=1, \ldots, \mathrm{n} ; \text { dan } \mathrm{j}=1, \ldots, \mathrm{n},
$$

Apabila nilai hitung chi-square lebih besar dari nilai kritis (nilai tabel) chi-square, maka hipotesis nol $\left(H_{0}\right)$ ditolak, yang berarti bahwa variabel $\mathrm{X}$ dan $\mathrm{Y}$ memeliki hubungan/berasosiasi, baik secara sangat kuat ( $\alpha=1 \%)$, kuat $(\alpha=5 \%)$, atau sedang ( $\alpha=10 \%)$. Sebaliknya, apabila nilai hitung chi-square lebih kecil daripada nilai kritis (nilai tabel) chi-square, maka hipotesis nol $\left(H_{0}\right)$ diterima yang berarti bahwa tidak ada hubungan/asosiasi antara variabel $\mathrm{X}$ dan $\mathrm{Y}$.

\section{KERANGKA PEMIKIRAN}

\subsection{Maturitas Manajemen Risiko}

Maturitas manajemen risiko digambarkan sebagai suatu ukuran yang dapat menunjukan tingkat efektivitas manajemen risiko. Dengan adanya pengukuran tingkat maturitas manajemen risiko, organisasi akan mampu mengidentifikasi area yang menjadi kekuatan dan kelemahan dalam penerapan manajemen risiko (Wendler, 2012). Selain itu, Oliva (2016) mengemukakan bahwa penerapan manajemen risiko yang mengacu pada hasil penilaian tingkat maturitas manajemen risiko akan memberi manfaat bagi organisasi berupa efisiensi biaya dan optimalisasi profitabilitas. Yeo \& Ren (2009) juga menyatakan bahwa terdapat korelasi antara kematangan penerapan manajemen risiko dengan keberhasilan mencapai sasaran dan target yang dicanangkan pada suatu proyek.

Tingkat maturitas manajemen risiko akan memberikan penilaian penerapan manajemen risiko di seluruh organisasi yang mencakup kemampuan pengambilan keputusan organisasi hingga pengaruhnya terhadap kinerja bisnis perusahaan secara keseluruhan (Alijoyo et al, 2020). Dalam mengukur tingkat maturitas manajemen risiko tentunya akan sangat dipengaruhi oleh standar/acuan yang digunakan untuk mengukur tingkat kematangan penerapan manajemen risiko di organisasi.

Enterprise Risk Management Academy (ERMA) pada tahun 2020 telah mengeluarkan model penilaian maturitas manajemen risiko berbasis ISO 31000. Dalam model tersebut, kriteria maturitas manajemen risiko ditetapkan menjadi lima tingkatan, yaitu :

\section{Initial}

ERMA mendefinisikan bahwa organisasi yang berada pada tingkatan initial memiliki pengelolaan risiko yang masih bersifat ad hoc, mengandalkan inisiatif individual, dan bersifat silo/terbatas pada suatu aspek risiko tertentu serta masih mengandalkan tindakan perbaikan sebagai dasar perlunya pengelolaan risiko.

\section{Repeatable}

Organisasi yang berada pada tingkatan repeatable memiliki pengelolaan risiko yang mulai berlangsung secara sistematis, namun masih cenderung terpisah dari tata kelola dan pengelolaan organisasi. Dari aspek dukungan kompetensi, kepemimpinan, dan komitmen manajemen risiko, organisasi pada tingkatan ini masih belum didukung secara merata.

\section{Defined}

Pada organisasi yang memiliki tingkatan defined, pengelolaan risiko telah berlangsung secara sistematis dengan mengacu pada suatu standar tertentu yang diterapkan secara konsisten dan menyeluruh. Pada tingkatan ini, pengelolaan risiko mulai 
terintegrasi dengan tata kelola dan pengelolaan organisasi. Dukungan kompetensi, kepemimpinan, dan komitmen manajemen risiko mulai meluas namun dengan perilaku positif dalam mengelola risiko yang cenderung masih terbatas.

\section{Managed}

Pada tingkatan ini, pengelolaan risiko organisasi telah terintegrasi dengan tata kelola dan sebagian besar aspek pengelolaan organisasi. Selain itu, pengelolaan risiko pada tingkatan maturitas managed telah menjadi budaya. Dukungan kompetensi, kepemimpinan, dan komitmen manajemen risiko organisasi sangat kuat serta perilaku positif dalam mengelola risiko yang merata di sebagian lingkungan organisasi. Pada tingkatan ini pula, dukungan dari mekanisme tinjauan, perbaikan, dan peningkatan sesuai kebutuhan dilaksanakan secara konsisten.

\section{Optimizing}

Bagi organisasi dengan tingkatan maturitas ini, pengelolaan risiko merupakan bagian yang tidak dapat terpisahkan dari tata kelola dan pengelolaan organisasi karena telah menjadi budaya organisasi yang mengakar dan terinternalisasi. Pada tingkatan ini, dukungan kompetensi, kepemimpinan, dan komitmen penerapan manajemen risiko yang kokoh, serta perilaku positif dalam pengelolaan risiko yang sudah mewujud di berbagai tingkatan organisasi. Pada tingkatan ini pula, dukungan dari mekanisme tinjauan, perbaikan, dan peningkatan sesuai kebutuhan spesifik dilaksanakan secara konsisten.

\subsection{Faktor yang mempengaruhi efektivitas manajemen risiko}

Efektivitas manajemen risiko di organisasi dapat dipengaruhi oleh berbagai faktor, baik internal maupun eksternal. Faktor ektsernal yang dapat mempengaruhi efektivitas manajemen risiko organisasi antara lain adalah faktor regulasi. Regulasi dapat diartikan sebagai faktor yang akan memaksa organisasi untuk mematuhi ketentuan regulasi untuk menerapkan manajemen risiko. Kepatuhan perusahaan terhadap pedoman dan norma yang ditetapkan baik dari internal perusahaan maupun eksternal organisasi merupakan faktor yang tidak dapat terpisahkan dalam menentukan keberhasilan penerapan manajemen risiko (Shimpi, 2005).

Selain faktor eksternal, faktor internal merupakan faktor yang sangat berpengaruh dalam mendukung efektivitas penerapan manajemen risiko organisasi. Beberapa penelitian terdahulu mengemukakan temuan mengenai faktor penentu efektivitas manajemen risiko yang berkaitan dengan faktor internal, diantaranya:

- Ranong dan Phuenngam (2009) meneliti penerapan manajemen risiko di industri keuangan Thailand, khususnya industri perbankan, pasar saham, asuransi, sekuritas, manajemen aset, dan sebagainya. Dengan metode survei yang melibatkan 34 pimpinan korporasi sebagai responden, penelitian ini memperoleh hasil bahwa faktor penentu efektivitas implementasi manajemen risiko, yaitu komitmen dan dukungan dari pucuk pimpinan, komunikasi, budaya, teknologi informasi, struktur organisasi, pelatihan, dan trust (kepercayaan).

- Kikwasi (2018) meneliti mengenai faktor yang mendukung efektivitas implementasi manajemen risiko di sektor industri infrastruktur (konstruksi bangunan) di Tanzania. Penelitian ini melibatkan 67 praktisi sebagai responden. Penelitian ini menemukan bahwa faktor kritis penentu keberhasilan implementasi MR yang efektif adalah pendekatan manajemen, tujuan dan sasaran organisasi, kebijakan dan pakar MR, 
teknologi dan budaya informasi, lingkungan dan penggunaan peralatan, kerja sama dan komitmen pimpinan puncak, komunikasi dan pelatihan, kesadaran tentang proses dan persyaratan legal MR, dan pemantauan dan peninjauan atas risiko.

- Zhao et al (2013) melakukan penelitian mengenai critical success factors yang menentukan keberhasilan implementasi manajemen risiko dalam perusaahaanperusahaan konstruksi di Tiongkok. Dalam penelitian ini melibatkan 89 praktisi sebagai respondennya. Penelitian ini menemukan bahwa terdapat tiga faktor utama yang mempengaruhi keberhasilan implementasi manajemen risiko, yaitu komitmen pimpinan puncak dan staf senior, proses asesmen risiko (identifikasi dan analisis) dan tindak lanjut perlakuan atas risiko, dan penetapan tujuan. Dalam penelitian ini juga mengemukakan bahwa pada dasarnya faktor penentu keberhasilan manajemen risiko dapat dipilah menjadi tiga kelompok, yaitu eksekusi dan integrasi, komunikasi dan pemahaman, serta komitmen dan keterlibatan manajemen puncak.

- Mensah dan Gottwald (2015) meneliti mengenai critical succes factors dalam implementasi manajemen risiko dengan melibatkan 134 praktisi manajemen risiko sebagai responden. Penelitian ini menemukan adanya korelasi yang kuat antara peran Chief Risk Officer, keberadaan Audit Committee dan dukungan dari Top Management, serta tingkat pengerahan (deployment level) enterprise risk management.

- Penelitian yang dilakukan oleh Kabuye et al (2019) meneliti mengenai pentingnya tone at the top dari pimpinan puncak serta kualitas internal audit terhadap efektivitas manajemen risiko. Data diperoleh dengan cara pengumpulan kuesioner dari 62 praktisi di bidang jasa keuangan. Hasil dari penelitian menemukan bahwa faktor kunci keberhasilan manajemen risiko adalah adanya komitmen dari pimpinan melalui penciptaan tone at the top serta kualitas dari internal audit.

- Sari et al (2018) meneliti mengenai pengaruh budaya organisasi dan pengendalian internal (internal control) terhadap tata kelola perusahaan dan kinerja perusahaan. Data diperoleh melalui survei yang dilakukan kepada 270 responden di BUMN Indonesia. Penelitian ini menemukan bahwa budaya organisasi, pengendalian internal, serta corporate governance berpengaruh positif dan signifikan terhadap kinerja perusahaan khususnya pada BUMN di Indonesia. Dalam penelitian ini juga disimpulkan bahwa tata kelola perusahaan merupakan variabel intervening yang memediasi hubungan antara budaya organisasi dan kinerja perusahaan.

- Newman et al (2018) melakukan kajian pustaka mengenai efektivitas sistem manajemen risiko terhadap kinerja keuangan. Dari hasil kajian, ditemukan bahwa faktor penentu keberhasilan implementasi manajemen risiko, yaitu komitmen manajemen, mengintegrasikan MR dalam proses bisnis, keterampilan komunikasi, dan pengetahuan dalam pengelolaan risiko. Adanya kesenjangan pengetahuan yang terjadi disebabkan karena kurangnya pelatihan, khususnya dalam hal teknis manajemen risiko.

- Agarwal and Kallapur (2018) meneliti pengaruh budaya risiko terhadap efektivitas tata kelola risiko di perusahaan asuransi. Berdasarkan studi yang dilakukan, perusahaan asuransi di Inggris Raya berhasil mengubah dari budaya risiko berbasis kepatuhan dan defensif menjadi budaya risiko kognitif dengan menggunakan pendekatan pemikiran sistem. Budaya risiko kognitif memastikan bahwa setiap orang memahami risiko dan peran mereka sendiri dalam tata kelola risiko. Perubahan tersebut dicapai dengan menambahkan lapisan operasional antara lini pertahanan pertama dan kedua dan 
mengembangkan alat untuk mengkomunikasikan risiko dengan lebih baik ke seluruh organisasi.

- Kurniawan et al (2017) meneliti mengenai pengaruh budaya risiko dalam memitigasi kerentanan dalam rantai pasok. Dengan menggunakan data dari 209 perusahaan manufaktur di Indonesia, diperoleh hasil bahwa budaya manajemen risiko menjadi faktor yang menghindarkan kerentanan pada rantai pasok. Penerapan strategi ini membutuhkan keterlibatan manajemen puncak dalam pengambilan keputusan berbasis risiko serta partisipasi aktif dari karyawan. Untuk menunjang budaya risiko maka perlu adanya program pelatihan untuk personel, pemasok, dan menilai kinerja pemasok (dalam kaitannya dengan risiko) penting dilakukan sebagai bagian dari mitigasi dalam rantai pasok.

- Drogalas et al (2017) meneliti mengenai peran dari internal audit dan manajemen dalam menunjang efektivitas manajemen risiko di 209 perusahaan Yunani. Berdasarkan penelitian, audit internal berbasis risiko, keterlibatan auditor internal dalam manajemen risiko dan dukungan manajemen puncak berkontribusi positif terhadap manajemen risiko yang efektif.

- Mardessi \& Ben Arab (2017) meneliti faktor yang mempengaruhi implementasi manajemen risiko di Tunisia. Berdasarkan data yang diperoleh dari 80 responden, ditemukan bahwa terdapat tiga faktor signifikan yang teridentifikasi mempengaruhi keberhasilan strategi implementasi manajemen risiko, yaitu faktor yang berasal dari manajemen (komitmen dari manajemen dalam hal pelaksanaan pengelolaan risiko), karakteristik dan komposisi perusahaan (termasuk ukuran perusahaan, jenis industri, tingkat pertumbuhan penjualan, independensi direksi dan audit, struktur kepemimpinan), dan pengukuran kinerja perusahaan (seperti Return on Assets, Return on Equity, dan Return on Sales).

- Priyarsono \& Munawar (2020) meneliti mengenai pentingnya pengembangan SDM untuk meningkatkan efektivitas pelaksanaan manajemen risiko organisasi. Data yang digunakan untuk penelitian diperoleh melalui survei yang melibatkan 309 responden. Penelitian ini menemukan bahwa implementasi manajemen risiko mampu meningkatkan daya saing ekonomi bagi organisasi implementornya maupun bagi anggota-anggota organisasi itu, kualitas pengembangan sumber daya manusia (SDM) manajemen risiko bepengaruh positif terhadap kualitas implementasi manajemen risiko, dan sertifikasi kompetensi manajemen risiko meningkatkan kualitas pelatihan manajemen risiko dan pada gilirannya meningkatkan kualitas pengembangan SDM manajemen risiko.

\section{HASIL DAN PEMBAHASAN}

Berdasarkan hasil pengumpulan data melalui survei, terdapat 55 responden yang memberikan tanggapan. Adapun sebaran responden berdasarkan klasifikasi jabatan adalah sebagai berikut: 


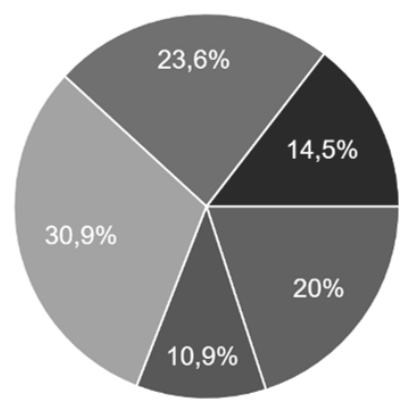

Staf atau sederajat.

Supervisor atau sederajat.

Manajer atau sederajat.

Direksi atau sederajat.

Komisaris atau sederajat.

\section{Gambar 1. Sebaran responden berdasarkan jabatan}

$30,9 \%$ responden memiliki jabatan manajer atau sederajat. Kemudian $23,6 \%$ responden merupakan responden dengan jabatan direksi atau sederajat dan $14,5 \%$ responden merupakan responden dengan jabatan komisaris atau sederajat. Sementara, untuk konsentrasi pada tingkatan supervisor atau sederajat adalah sebesar 10,9\% dan $20 \%$ responden merupakan responden pada tingkatan staf atau sederajat. Hal ini memberikan gambaran bahwa responden yang memberikan tanggapan beragam pada berbagai tingkatan jabatan.

Berdasarkan jenis organisasi, didominasi oleh responden yang berasal dari organisasi swasta dengan konsentrasi sebesar 69,1\%. Sementara untuk responden yang berasal dari lembaga pemerintah dan BUMN adalah masing-masing sebesar 18,2\% dan 12,7\%. Sementara itu, dengan mengelompokan berdasarkan jenis industri, didominasi oleh responden yang berasal dari lembaga jasa keuangan (25,5\%), jasa pendidikan $(14,5 \%)$, dan konstruksi $(9,1 \%)$.

\subsection{Faktor yang mempengaruhi maturitas manajemen risiko organisasi}

Untuk mengetahui faktor yang mempengaruhi maturitas manajemen risiko organisasi, data diolah dengan menggunakan contingency table analysis. Berdasarkan hasil jawaban responden dalam survei, setiap komponen variabel dikoinsidensikan dengan variabel maturitas manajemen risiko organisasi sehingga bisa diperoleh hasil bagaimana perbedaan persepsi pada berbagai tingkat maturitas berhubungan dengan variabel lainnya. Berdasarkan hasil pengelolaan data, diperoleh hasil sebagai berikut:

Tabel 2. Hasil estimasi menggunakan metode contigency table analysis.

\begin{tabular}{|c|l|c|}
\hline No. & \multicolumn{1}{|c|}{ KOMPONEN } & Prob. \\
\hline 1. & Kejelasan Struktur Tata Kelola & $0,000^{* * *}$ \\
\hline 2. & Komitmen Pimpinan & $0,033^{* *}$ \\
\hline 3. & Kebijakan dan Prosedur & $0,000^{* * *}$ \\
\hline 4. & Kaji Ulang Struktur Tata kelola, Kebijakan, dan Prosedur & $0,000^{* * *}$ \\
\hline 5. & Program Pelatihan Berjenjang & $0,001^{* * *}$ \\
\hline 6. & Sertifikasi Kompetensi Manajemen Risiko & $0,649^{*}$ \\
\hline 7. & Sistem Manajemen & $0,057^{*}$ \\
\hline 8. & Integrasi Sistem Manajemen dengan Manajemen Risiko & $0,001^{* * *}$ \\
\hline 9. & Sistem Penilaian Kinerja Organisasi & $0,191^{`}$ \\
\hline 10. & Sistem Penilaian Kinerja Berbasis Risiko & $0,026^{* *}$ \\
\hline 11. & Sistem Pengelolaan Ketahanan Organisasi & $0,022^{* *}$ \\
\hline 12. & Integrasi Sistem Pengelolaan Ketahanan dengan Manajemen Risiko & $0,069^{*}$ \\
\hline 13. & Sistem Pengelolaan Keberlanjutan Organisasi & $0,002^{* * *}$ \\
\hline 14. & Integrasi Sistem Pengelolaan Keberlanjutan dengan Manajemen Risiko & $0,005^{* * *}$ \\
\hline
\end{tabular}




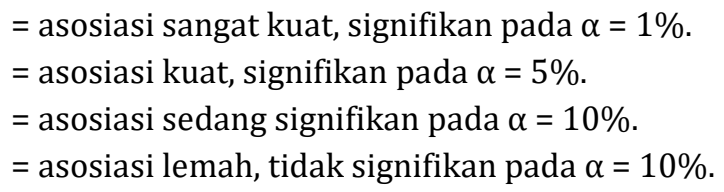

\subsubsection{Faktor Governance, Pedoman, dan Prosedur}

Terdapat koinsidensi yang sangat kuat $(\alpha=1 \%)$ antara kejelasan struktur tata kelola organisasi dengan tingkat maturitas di organisasi. Hal ini menandakan bahwa organisasi yang memiliki tingkat maturitas manajemen risiko yang tinggi memiliki struktur tata kelola yang jelas dan telah dilakukan kajian secara berkala mengenai dokumen struktur tata kelola. Sebaliknya, organisasi yang tidak menetapkan struktur tata kelola yang jelas (atau bahkan belum menetapkan secara formal) akan memiliki tingkat maturitas manajemen risiko yang rendah. Hal ini mempertegas pemahaman bahwa aspek governance akan menunjang maturitas manajemen risiko organisasi.

Sementara itu, pada aspek komitmen pimpinan, terdapat koinsidensi yang kuat ( $\alpha=5 \%)$ antara komitmen pimpinan dengan tingkat maturitas manajemen risiko organisasi. Organisasi yang memiliki tingkat maturitas yang rendah cenderung memiliki pimpinan yang tidak peduli pada aspek manajemen risiko organisasi. Sebaliknya, organisasi yang memiliki tingkat maturitas yang tinggi memiliki pimpinan yang sudah menyatakan visi mengenai manajemen risiko dan visi tersebut tercermin dalam rencana kerja. Hal ini menegaskan bahwa komitmen pimpinan dalam penerapan manajemen risiko sangat dibutuhkan. Pada kerangka kerja manajemen risiko berbasis SNI ISO 3100, pada bagian kerangka kerja ditegaskan bahwa inti yang akan mendorong efektivitas kerangka kerja dan pelaksanaan manajemen risiko organisasi adalah kepemimpinan dan komitmen pimpinan organisasi.

Aspek governance dapat diwujudkan dalam bentuk pedoman dan prosedur di organisasi. Berdasarkan hasil pengolahan data, terdapat koinsidensi yang sangat kuat $(\alpha=1 \%)$ antara tersedianya pedoman dan prosedur dengan tingkat maturitas manajemen risiko organisasi. Organisasi dengan tingkat maturitas yang tinggi (managed and optimizing) memiliki pedoman dan prosedur manajemen risiko yang konsisten dilaksanakan serta dikaji ulang secara berkala. Dengan adanya pedoman dan prosedur pada tahap awal penerapan manajemen risiko akan memaksa individu pada berbagai tingkatan di organisasi untuk melaksanakan prosedur pengelolaan risiko organisasi. Dengan melakukan review yang berkala, organisasi memastikan kesesuaian dari pedoman dan prosedur dengan konteks terkini organisasi.

Program kaji ulang juga memainkan peran dalam menunjang efektivitas manajemen risiko organisasi. Terdapat koinsidensi yang sangat kuat $(\alpha=1 \%)$ antara program kaji ulang terhadap struktur, pedoman, dan prosedur dengan tingkat maturitas manajemen risiko organisasi. Program audit dapat memastikan bahwa pelaksanaan manajemen risiko dijalankan sesuai dengan standar yang ditetapkan. Berdasarkan penelitian Droglas et al (2017) serta Kabuye et al (2017) kualitas dari program audit akan menunjang efektivitas penerapan manajemen risiko.

\subsubsection{Kompetensi SDM}

Terdapat koinsidensi yang sangat kuat $(\alpha=1 \%)$ antara program pelatihan berjenjang dengan tingkat maturitas manajemen risiko organisasi. Organisasi yang memiliki program pelatihan manajemen risiko yang berjenjang untuk setiap tingkatan jabatan cenderung memiliki 


\section{6| Bina Ekonomi}

tingkat maturitas penerapan manajemen risiko yang lebih tinggi. Hal ini sejalan dengan penelitian Priyarsono \& Munawar (2020) yang menekankan pentingnya pengembangan sumber daya manusia (SDM) dalam menunjang pelaksanaan manajemen risiko organisasi dan budaya sadar risiko di organisasi.

Koinsidensi yang lemah $(\alpha>10 \%)$ ditemukan antara program sertifikasi kompetensi manajemen risiko dengan tingkat maturitas manajemen risiko di organisasi. Hal ini tejadi karena hampir 99\% responden menjawab bahwa sertifikasi kompetensi manajemen risiko sangat penting sehingga responden pada berbagai tingkatan maturitas menyatakan bahwa sertifikasi kompetensi manajemen risiko penting untuk menunjang efektivitas penerapan manajemen risiko organisasi.

\subsubsection{Sistem Manajemen}

Terdapat koinsidensi dengan tingkat sedang $(\alpha=10 \%)$ antara sistem manajemen dengan tingkat maturitas manajemen risiko organisasi. Organisasi yang sudah memiliki sistem manajemen cenderung memiliki tingkat maturitas manajemen risiko yang lebih tinggi. Sementara itu, terdapat koinsidensi yang sangat kuat $(\alpha=1 \%)$ antara tingkat maturitas manajemen risiko dengan sistem manajemen yang terintegrasi manajemen risiko. Organisasi yang sudah memiliki sistem manajemen yang terintegrasi dengan manajemen risiko cenderung memiliki tingkat maturitas manajemen risiko yang lebih tinggi. Dengan kata lain, organisasi dengan tingkat maturitas managed dan optimize telah mengintegrasikan manajemen risiko dalam pengelolaan sistem manajemen yang ditetapkan di organisasi.

\subsubsection{Sistem Penilaian Kinerja}

Terdapat koinsidensi yang lemah $(\alpha>10 \%)$ antara sistem penilaian kinerja dengan tingkat maturitas manajemen risiko organisasi. Responden cenderung menyatakan bahwa organisasinya telah menetapkan sistem penilaian kinerja sehingga perbedaan tingkat maturitas manajemen risiko tidak berhubungan dengan adanya sistem penilaian kinerja pada suatu organisasi. Sementara itu, koinsidensi yang kuat $(\alpha=5 \%)$ ditemukan antara sistem penilaian kinerja berbasis risiko dengan tingkat maturitas manajemen risiko organisasi. Hal ini menandakan bahwa organisasi yang memiliki tingkat maturitas tinggi sudah mempertimbangkan pengelolaan risiko sebagai bagian dari sistem penilaian kinerja organisasi.

\subsubsection{Sistem Pengelolaan Ketahanan}

Terdapat koinsidensi yang kuat $(\alpha=5 \%)$ antara pengelolaan ketahanan dengan tingkat maturitas manajemen risiko organisasi. Organisasi yang memiliki tingkat maturitas tinggi mulai mempertimbangkan adanya sistem pengelolaan ketahanan bagi organisasi. Sementara itu, ditemukan koinsidensi dengan tingkat sedang $(\alpha=10 \%)$ antara pengelolaan ketahanan yang terintegrasi dengan manajemen risiko dengan tingkat maturitas manajemen risiko organisasi. Organisasi dengan tingkat maturitas yang rendah, belum mempertimbangkan adanya pengelolaan ketahanan bagi organisasi, apalagi mengintegrasikannya dengan manajemen risiko organisasi. Organisasi pada tingkat maturitas initial cenderung berfokus pada pengelolaan risiko yang bersifat ad hoc atau pada risiko-risiko tertentu (misalnya diharuskan oleh regulasi) sehingga belum mempertimbangkan pengelolaan risiko yang terintegrasi dengan pengelolaan ketahanan 
organisasi. Sementara itu, bagi organisasi dengan tingkat maturitas yang lebih tinggi sudah mempertimbangkan aspek pengelolaan ketahanan dan mengintegrasikannya dengan sistem manajemen risiko organisasi.

\subsubsection{Sistem Pengelolaan Keberlanjutan}

Terdapat koinsidensi yang kuat $(\alpha=1 \%)$ antara pengelolaan sustainabilitas atau keberlanjutan dengan tingkat maturitas manajemen risiko organisasi. Sama halnya dengan hubungan antara tingkat maturitas dengan pengelolaan ketahanan, organisasi dengan tingkat maturitas yang rendah belum mempertimbangkan pengelolaan keberlanjutan organisasi. Sementara itu, bagi organisasi dengan tingkat maturitas yang tinggi mulai mempertimbangkan pentingnya aspek pengelolaan keberlanjutan bagi organisasi.

Ditemukan koinsidensi yang kuat $(\alpha=1 \%)$ antara pengelolaan sustainabilitas atau keberlanjutan yang terintegrasi dengan manajemen risiko dengan tingkat maturitas manajemen risiko organisasi. Bagi organisasi dengan tingkat maturitas yang tinggi pengelolaan risiko mulai berfokus pada pengelolan risiko untuk menunjang aspek keberlanjutan dari organisasi.

\section{KESIMPULAN}

Faktor yang mempengaruhi tingkat maturitas manajemen risiko suatu organisasi akan berbeda, tergantung dengan konteks yang dihadapi oleh organisasi. Berdasarkan hasil survei dan pengolahan data menggunakan teknik contigency table analysis diperoleh hasil bahwa faktor utama yang akan mempengaruhi tingkat maturitas manajemen risiko organisasi adalah struktur governance, pedoman, dan prosedur yang jelas serta didukung oleh komitmen pimpinan dan kaji ulang secara berkala, sumber daya manusia yang memiliki kompetensi dalam bidang manajemen risiko untuk menciptakan budaya sadar risiko organisasi, pengelolaan sistem manajemen dan kinerja yang terintegrasi, serta sistem pengelolaan ketahanan dan keberlanjutan organisasi.

Penelitian ini memiliki keterbatasan dimana tidak secara langsung mengukur tingkat maturitas dari organisasi masing-masing responden. Dalam penelitian ini hanya menggunakan persepsi dari responden terhadap tingkat maturitas manajemen risikonya yang kemudian responden ditanyakan lebih lanjut terkait dengan kondisi berbagai faktor yang terdapat di organisasinya. Penelitian secara tersetruktur mengenai tingkat maturitas organisasi bisa menjadi usulan untuk penelitian selanjutnya agar dapat memperoleh gambaran lebih tepat mengenai tingkat maturitas manajemen risiko organisasi. 


\section{DAFTAR PUSTAKA}

Agarwal, R., \& Kallapur, S. (2018). Cognitive risk culture and advanced roles of actors in risk governance: a case study. The Journal of Risk Finance.

Agyei-Mensah, B. K., \& Buertey, S. (2019). Do culture and governance structure influence extent of corporate risk disclosure? International Journal of Managerial Finance.

Alijoyo, F. A., Hendra, R., \& Sirait, K. B. (2020). The State-of-The-Art of Enterprise Risk Management Maturity Models: A Review. Manuscript submitted for publication.

Drogalas, G., Eleftheriadis, I., Pazarskis, M., \& Anagnostopoulou, E. (2017). Perceptions about effective risk management: The crucial role of internal audit and management Evidence from Greece. Investment management and financial innovations, 14(4), 1-11.

Mensah, G., \& Gottwald, W. (2015). Enterprise Risk Management: Factors Associated with Effective Implementation.https://web.actuaries.ie/sites/default/files/ermresources $/ 100$ factors effective ERM implementation.pdf.pdf

Kabuye, F., Bugambiro, N., Akugizibwe, I., Nuwasiima, S., \& Naigaga, S. (2019). The influence of tone at the top management level and internal audit quality on the effectiveness of risk management practices in the financial services sector. Cogent Business \& Management, 6(1)

Karyani, E., Dewo, S. A., Santoso, W., \& Frensidy, B. (2019). Risk governance and bank profitability in ASEAN-5: a comparative and empirical study. International Journal of Emerging Markets.

Kikwasi, G. J. (2018). Critical Success Factors for Effective Risk Management. In Risk Management Treatise for Engineering Practitioners. Intech Open.

Kurniawan, R., Zailani, S. H., Iranmanesh, M., \& Rajagopal, P. (2017). The effects of vulnerability mitigation strategies on supply chain effectiveness: risk culture as moderator. Supply Chain Management: An International Journal.

Kateri, M. (2014). Contingency table analysis: Methods and implementation using $R$ (1st ed.). Aachen, Germany: Editorial Advisory Booard.

Mardessi, S. M., \& Arab, S. D. B. (2018). Determinants of ERM implementation: the case of Tunisian companies. Journal of Financial Reporting and Accounting.

Newman, W., Charity, M., Faith, S., \& Ongayi, W. (2018). Literature review on the effectiveness of risk management systems on financial performance in a public setting. Academy of Strategic Management Journal, 17(4), 1-12.

Oliva, F. L. (2016). A maturity model for enterprise risk management. International Journal of Production Economics, 173, 66-79.

Priyarsono, D.S., \& Munawar, Yusuf. (2020). Pengembangan SDM untuk Implementasi Manajemen Risiko: Perspektif Baru dari Sudut Pandang Pengguna. Jurnal Aplikasi Bisnis dan Manajemen.

Shimpi, P. (2005). Enterprise risk management: from compliance to value; A unifying framework can help companies identify and articulate risks consistently across the enterprise and evaluate alternative capital structures to bear those risks. Financial Executive, 21(6), 52-55. 
Sari, M., Lubis, A. F., Maksum, A., Lumbanraja, P., \& Muda, I. (2018). The Influence of Organization's Culture and Internal Control to Corporate Governance and Its Impact on State-Owned Enterprises Corporate. Journal of Applied Economic Sciences, 13(3).

Wendler, R. (2012). The maturity of maturity model research: A systematic mapping study. Information and software technology, 54(12), 1317-1339.

Yang, S., Ishtiaq, M., \& Anwar, M. (2018). Enterprise risk management practices and firm performance, the mediating role of competitive advantage and the moderating role of financial literacy. Journal of Risk and Financial Management, 11(3), 35.

Yeo, K. T., \& Ren, Y. (2009). Risk management capability maturity model for complex product systems (CoPS) projects. Systems Engineering, 12(4), 275-294.

Zhao, X., Hwang, B. G., \& Low, S. P. (2013). Critical success factors for enterprise risk management in Chinese construction companies. Construction Management and Economics, 31(12), 1199-1214. 